\title{
Nonparticipation in University Language Support
}

\author{
Hayo Reinders \\ University of Auckland
}

Research has shown that many students studying abroad face great difficulties and run the risk of failing courses as a result of problems with the language (cf. Ballard \& Clanchy, 1997). At a university in New Zealand it was found that over $70 \%$ of all resident second language speakers had a level of English that did not prepare them adequately for university study. In response, a free language support programme was offered to help students improve their English and develop their skills for independent learning. Students with identified language needs were strongly encouraged to take part in the programme. However, both the participation and completion rates were disappointing, especially among Japanese students. Several previous studies have reported similar findings, but little information is available on the reasons for this lack of participation (e.g. Voller, Martyn, \& Pickard, 1999; Mak \& Turnbull, 1999). The current study is an attempt to investigate why, in spite of strong encouragement, students chose to (not) make use of the available support and what determined their completion of the programme. It was found that while time constraints played an important role, so did students' perceptions of the programme and the type of support it would offer. A number of practical recommendations for support staff working on such programmes are given.

先行研究では、留学中の学生の多くが、語学的な問題のために、学業の困難に直面し、 落第の危機にさらされていることが示されている(cf. Ballard, \& Clanchy 1997)。ニュージ 一ランドの一大学では、英語を第 2 国語として話す学生全体の $70 \%$ 上が、大学での勉 強に十分に対応できるだけの英語力が備わっていないことが判明した。それに対応する形 で、学生の英語力と、自立的な学習スキルの向上を助けるために、無料の語学サポートプ ログラムが提供された。語学的必要が認められている学生には、強くこのプログラムへの 参加が促された。しかしながら、参加率、終了率のどちらを見ても、期待はずれなもの で、これは、特に日本人の学生の間で、顕著であった。多くの先行研究が、これに似た結 果を報告しているが、このような非参加の理由に関しては、情報が非常に少ない。本研究 では、なぜ学生達が利用できるサポートを利用した（あるいはしなかった）のか、そし

JALT Journal, Vol. 27, No. 2, November, 2005 
て、何がこのプログラムの終了の要因となつたのか、を調査するひとつの試みである。時 間的な制約のみではなく、学生のプログラムとこれが提供するだろうサポート内容の性格 に対する印象も、重要な役割を果たしたことが判明した。最後に、このようなプログラム に従事するサポートスタッフのための、実用的な提案を示す。

\section{Language Support}

With the growth in the number of international students worldwide the provision of language support has become an increasingly important issue in tertiary education. Other than through classroom teaching, one of the most common types of support is self-access facilities (Benson \& Voller, 1997). Self-access has been defined as "a number of resources (in the form of materials, activities, and support), usually in one place, that accommodates learners of different levels, styles, and with different goals and interests. It aims at developing learner autonomy among its users" (Cotterall \& Reinders, 2001, p. 25). One of the main advantages of self-access in a tertiary context is that it provides flexibility; students can use the facilities at their leisure and work according to their needs. Selfaccess is also seen as a way for students to develop skills for independent learning. Two important issues in the area of self-access have been how to encourage students to spend time on improving their language (especially if, as in most cases, this is done voluntarily and is not credited), and how to provide appropriate support for their (self-)study. In recent years, language advisory services have become an increasingly popular type of service offered in self-access centres (and sometimes as a stand-alone service or as part of language courses), especially aimed at addressing the latter concern. Language advising or language counselling consists of one or more meetings between an advisor and a student, usually oneto-one. The student can ask questions, and the advisor gives feedback and makes recommendations. Together, advisor and student can analyse language needs and wants, make a study plan, and discuss any aspect of the student's learning. The potential beneficial effects of such sessions on students' motivation and awareness have been well documented (cf. Mozzon-McPherson \& Vismans, 2001). Since in self-access centres many students come infrequently due to their course demands, language advising can increase the otherwise limited opportunities for contact between staff and students. One thing that many advisory sessions have in common, though, is that participation tends to be voluntary and ad hoc; structured programmes are less common.

The voluntary aspect of many language advisory sessions can be problematic. Voller, Martyn, \& Pickard (1999), for example, report that 
sessions often lack clear objectives and fail to provide learners with an opportunity to acquire appropriate study techniques. One of the findings from their study was that a change from a drop-in service to a more structured programme resulted in students coming more often. When students do not return it is often difficult to establish why and this has a negative impact on the staff. Fu (1999) writes, "A person will come for what the counsellor perceives is a substantial and interesting discussion or learning dialogue, and then the counsellor never sees that person again, therefore getting neither any feedback nor report on progress (or lack of it)" (p. 107). This does not necessarily mean that the session has been fruitless. As Fu points out "a seed may have been planted" (p. 107), but this is difficult to tell.

Possibly as a result of the voluntary nature of this type of support, several studies report rather low return rates. Voller, Martyn, \& Pickard (1999) report that of their 32 participants, 12 (i.e. 38\%) attended only one session, seven (22\%) attended two sessions, and 13 (40\%) more than two. In a later programme, $30 \%$ of the students attended four or more sessions. The authors suggest more research should be done to establish whether "...the reasons for this are structural, caused for instance by a lack of time in students' schedules, to do with the process of consultation, or a mixture of both" (p. 123). Mak \& Turnbull (1999) report a dropout rate of $15 \%$ (8 out of 51 participants) in an intensive advisory programme which required participants to attend three sessions. The authors did not investigate the reasons why students withdrew but speculate that several "simply seemed too immature in their attitudes towards themselves as learners to benefit from a programme of this nature" (p. 50). Unfortunately, little formal research has been done to investigate why some students decide not to continue their participation in such programmes. Various studies (investigating not only advisory programmes but also self-access in general) speculate that students' limited time for language study may play a role (Pemberton, Ho, Lam, \& Toogood, 1999), as well as students' resistance to self-study as opposed to teacher-led instruction (Tsang, 1999), and students' lack of previous experience with such support (Hiemstra \& Brockett, 1994).

Return figures obtained from an advisory support programme offered at our university in 2002 (Reinders, in press b) compare somewhat favourably with the aforementioned studies. Of the 54 participants, 8 completed only one session. The remaining 46 (85\%) attended two or more sessions and the average number of sessions was four, over an average of seven weeks. However, the advisors working on the programme 
reported many "no-shows," students who had made an appointment but did not come without informing them. No formal feedback was obtained from students who only attended one session or who failed to show up for appointments. However, advisors working on the programme spoke to some of the participants and found that they had felt under a lot of pressure to complete their regular course work and did not have time for the support programme. Advisors also felt that students may have had expectations of the programme that were not met. The present study is an attempt to delve deeper into the causes for nonparticipation and noncompletion in language support programmes such as this.

\section{The Study}

A recent survey conducted at the university where this study took place revealed that approximately $40 \%$ of all students claim a language other than English as their first language with most having a Chinese, Korean, or Japanese background. Students and staff report numerous language-related problems. One internal report (Elder, 2004) has shown that approximately $70 \%$ of the second language students at our university who are residents of New Zealand (and who, unlike international students, are not required to provide evidence of their English abilities for enrolment, such as IELTS or TOEFL scores) have a level of English considered too low for them to be successful at university. It also showed that students who are less proficient in English are up to three times more likely to fail their courses than more proficient students. From our own experience Japanese learners are comparatively overrepresented both as those with lower language proficiency and as those who are more likely to fail their courses (at least in the first year). The language issue is clearly a crucial one for many of these students. In response to this, a diagnostic English language-needs assessment was developed. This is an assessment of reading, writing, and listening skills and is given to most first-year students in order to identify those with potential language problems and to direct them to appropriate language support.

There are various types of support available to students at the university, most notably credit-bearing language courses for those who are in need of an intensive type of training (those with diagnostic assessment scores in the lowest two bands). For others (mainly those with diagnostic assessment scores in the middle two bands as well as for further practice to those enrolled in the language courses), a flexible option exists in the form of a self-access centre. The Centre is open seven days per week and 
offers access to around 1,100 language learning materials, skills-based workshops, and a language advisory service (whose website is available at www.elsac.auckland.ac.nz). The Centre also offers an electronic learning environment developed in-house. This computer programme gives students access to (electronic) language learning resources and supports students in their self-directed learning (Reinders, in press a). The Self-Access Centre was set up to assist the potentially very large numbers of students in need of help (over 700 students are currently enrolled) to develop the skills necessary to improve their English by themselves, both for economical reasons (self-study is sometimes percieved to be less expensive and not everyone can be helped through regular teaching) as well as the pedagogical motivation to prepare students for the (changing) future demands on their language ability. Many students report great difficulties when moving on to postgraduate studies or when applying for jobs; they are often not ready for the (language) demands of the workplace. Part of the Centre's mission is to prepare them for those situations. To do so, the Centre has made it part of its mission statement to foster learner autonomy by encouraging critical reflection, by developing planning and evaluation strategies, and by increasingly handing over control of the learning process to the students.

In 2002 and 2003, the Self-Access Centre successfully tendered for government funding to develop and deliver an intensive advisory programme over the summer breaks. As part of the programme, students met regularly with an advisor over a period of three months. A similar service had always been available in the Centre, but due to limited staffing only one or two meetings could be held with individual students. As part of this new programme, two dedicated advisors, both Japanese teachers living in New Zealand, were available to provide assistance. The programme aimed to develop both language skills and independent learning skills and to gradually reduce the amount of support over time in order to allow students to work on their own, while still providing monitoring and feedback when necessary. In their first one-on-one advisory session students were made aware of the aims and format of the programme. It was made clear to students that both group workshops and one-to-one advisory sessions were available, but that the essence of the programme was their own independent learning using the electronic learning environment, that is, the bulk of the work was expected to be done by the students themselves, with counselling and guidance from the advisors. No credit was given for the programme although a certificate of attendance was awarded upon completion of three or more 
sessions.

Although all students at the university were eligible to enrol in the programme, primarily students who had sat the diagnostic assessment and had clearly identified language needs were approached. A total number of 1,100 students (the vast majority of them second language speakers) were invited by e-mail to join the programme. Of those, only a disappointing 105 participated. Even more disappointing was the fact that only 62 completed two or more sessions with their advisors. Naturally, we were interested in what caused these small numbers. The 1,100 students who had been contacted had taken a diagnostic assessment (as described above) and had been sent a profile which clearly showed their language proficiency was not up to the standard required for university study. Why did they not join this free programme? And why did many of those who did join not complete more sessions? Thus, the research questions of this study were:

1. What are the reasons students decide to take up language support or not?

2. What are the factors influencing continuation and completion of a self-study language support programme?

In order to answer the first question, students who had been invited to join the programme, but did not do so were sent a questionnaire asking them about their perceptions of the role of English in their studies, the types of support they felt they needed, and their reasons influencing the decision to not take up support (see Appendix A). Answers to the second question were obtained from the results of a different questionnaire, administered to those who did participate in the programme (see Appendix B). These students were asked about their opinion of the programme and the support they had received. ${ }^{1}$

\section{Results}

The questionnaire for students who did not participate in the programme was made available in electronic format on the Self-Access Centre's website and a request to complete it was sent to approximately 1000 students of whom 185 responded. This is not a very high percentage but a reasonably large number of responses nonetheless. The questionnaire presented the participants to rate a number of statements from 1 to 6 depending on whether they did not agree at all (1) or agreed completely (6). 
Most of the respondents strongly agreed with the first statement "Having good English ability is important to be a successful student" (5.6 out of 6 on average). Most also agreed with the statement "I need to improve my English" (rated 5). This is not surprising since all had received below-average diagnostic assessment scores. At least it shows they agreed there was room for improvement. The next question asked participants to select which of the four main skills they thought was most important for them. Writing was selected (42\%) well ahead of listening (19\%), speaking (18\%), and reading (17\%).

The following question asked participants if they had heard of the Self-Access Centre and its programme. Most of the respondents (88\%) indicated they had. Lack of knowledge of the available support was obviously not a factor determining overall participation in the programme.

The following section of the questionnaire told students they had been sent the questionnaire because they had not participated in the advisory programme and asked why they had chosen not to. Respondents agreed to some extent with the statement "I did not have enough time" (3.8 out of 6) and to a slightly lesser extent with the statement "I will make use of it in the future" (3.2 out of 6). However, respondents agreed more strongly with the statement, "I want to study with a teacher" ( 4.8 out of 6 ). When asked to rate a range of possible services from the Self-Access Centre, students indicated a preference for intensive support, similar to one-on-one teaching. Language learning activities scored high ( 4.8 out of 6 ) and so did proofreading ( 4.9 out of 6 ). The latter is a service that is not offered for financial reasons but also because it is felt to contravene the Centre's goal of fostering autonomy (the Centre does offer workshops on how to proofread one's own work and on giving and receiving peer-feedback). Clearly, the students see this differently.

The final question asked respondents for ideas to provide the best possible support in the Self-Access Centre. What follows below is a fairly typical response:

...run it like language school during the summer holiday time, i.e. a fixed group of student with the same teacher, so that we learn with the friendship with each other including the teacher, and having tests regularly so that we would know how we are going.

Students seemed to appreciate the structure and encouragement of an organised course and the incentive that tests can offer. In addition, several students, like the one quoted above, mentioned the benefits of working with others. (Incidentally, the Centre does offer a large number 
of workshops [around 250 per year] and opportunities for small-group study as well as a study-buddy programme that pairs students and supports them in their collaborative work. Obviously these activities are not widely known.)

The second questionnaire was sent to 67 students who had participated in the programme and for whom current contact details were known. Thirty-five of them responded and these included both students who had only attended one or two sessions and students who attended several sessions. In other words, it included students who could be considered to have completed the programme as well as those who could be considered to have not. The primary purpose of the questionnaire was to obtain feedback about the programme and for this reason it included a number of practical questions about the materials used, the frequency of the sessions, and so forth, in the hope that the results would also give insight into the reasons why some students did not continue the programme. Participants were asked to answer the questions by choosing from 1 (no, absolutely not) to 5 (yes, absolutely).

First, participants were very positive about the programme. When asked if they found the programme useful, they rated it 4.5 out of 5 (with only one student giving it a 3 out of 5). Students generally felt that the programme had helped them learn how to study English by themselves in the future (4.2) and had helped them focus on what they wanted to improve (4.4). They also felt it had helped them to set manageable goals (4.3), learn new strategies (4.2) and, importantly, had made them work on their English more (4.1). Students were also generally positive about their advisors, finding them supportive (4.5).

So if students generally appreciated the support, why did many of them not complete the programme? The questionnaire contained several open-ended questions, one of which was "What aspects of the advisory sessions did you find most useful?" Several students listed the opportunity to speak English, which interestingly was not the primary goal of the sessions (from the advisors' point of view):

I can speak more and practise understanding Kiwi speakers.

Others mentioned the feedback they could get on their writing which, again, was not the main purpose of the advisory sessions: 
A second question asked participants what learning strategies they had developed as a result of the programme. Most answers referred to either the ability to locate appropriate resources or to cognitive strategies:

Utilise different resource, aware useful resource are available for use.

Read efficiently, by skipping, scanning, summarizing etc.

Although these are of course useful it was somewhat unexpected that none of the participants referred to metacognitive strategies such as planning one's learning or assessing one's work, even though these formed an important and explicit part of the programme.

Another question asked for suggestions on how the programme could be improved. The answers are revealing in that they give the impression students view the sessions as a private language lesson. Some students asked for "more tuition [instruction]" and one student suggested:

Tell students what they should do rather than what they would like to do.

Several students asked for "a more structured programme." Students may have misunderstood the aim of the programme-to provide a supported self-study option - and the rationale behind it. Perhaps it was not communicated clearly enough. It may also be that the students did not see this type of programme as useful as one based on a clear curriculum such as in a classroom situation.

One additional indication of students' lack of commitment to the programme was the number of cancelled advisory sessions and the number of times students missed their appointments. Although no accurate record was kept of this, the fact that this happened many times was frustrating for the advisors and probably shows that the programme failed to encourage students to make time for it.

\section{Conclusions and Practical Recommendations}

The results from the two questionnaires show that students' perceptions of the support programme are rather different from the advisors'. Students, both those who did and those who did not participate in the programme, seem to be asking for more structure and tuition rather than for the more indeterminate type of support offered by the advisory sessions. 
In answering the first question of this study, "What are the reasons why students decide to take up support or not?" it was found that lack of knowledge of the programme was not an issue. Lack of time plays a role but students also seem to be unsure how the programme would help them or at least, express preference for a type of support that was not offered (cf. Reinders \& Cotterall, 2001). Likewise, when looking at the factors influencing continuation and completion of the programme, time also appeared to be an issue. Many students cancelled appointments or forgot about them and had to be reminded by their advisors. When asked, they cited study pressures. However, the results from the second questionnaire also show that students have a different view of the role of the programme and the advisory sessions than that intended by the advisors. Even though they felt positively about their advisors and generally found the sessions helpful in developing their strategies and their ability to work independently, they may have felt that the sessions, with their emphasis on learning skills, were not practical enough to warrant the time investment required. Several students wanted "more tuition" as part of the programme and this seems to echo comments made by respondents to the nonparticipation questionnaire. Fu (1999) describes this well when she says,

The approach [language counselling] may [...] seem vague and flexible to the users when we say, for example, that the counsellors can "give recommendations on language learning strategies for improving English" or "can help users design their personalized Language Improvement Plan." In other words, to these users what really is a "strategy" or what does "design" really mean? It may all seem rather confusing and appear to be just a lot of hard work. (p. 108)

This may be particularly true for the (mainly) Asian students who participated in this programme. Although one has to be cautious when making broad statements about groups of people from different countries and with different cultural backgrounds, it is not unlikely (and anecdotal evidence from the Centre staff seems to confirm this) that many of the students had not experienced the type of learning encouraged in the Self-Access Centre before. The ever-present focus on their own learning may have been alien to them, and possibly quite demanding. There is a constant balancing act between an approach to learning and teaching based on teachers' pedagogical beliefs, and one that takes into account students' prior experiences and expectations. 
It is important to note that the lack of participation in support programmes at the University is low in general, not just on the programme described here. The earlier cited internal study (Elder, 2004) found that of all assessed students who had been advised to take up some form of support less than $20 \%$ actually did so. Although the respondents to the first questionnaire indicated a preference for teacher support and even a service similar to "a language school," they did not take up that type of support in the form of the language courses that are available at the University. It seems that students do not give language study high priority in their university studies. It was suggested above that for those students who did participate in the programme, the lack of structure and the focus on learning skills may have been contrary to their expectations. However, considering that they chose the advisory programme and not an intensive language course, it is probably justified to ask what they were hoping to achieve. Some students may well have hoped for a "quick fix." Possibly their expectations of what could be achieved in a few hours with an advisor were unrealistic. This applies not only to the programme but also to many students' use of the Self-Access Centre in general; it is not uncommon for students to ask Centre staff to help them with their language a week before the exams start or an assignment is due.

However, it is unfair to put the blame on the students' shoulders. It is our job to help students and that includes making sure they understand the role of language study and their own responsibility in ensuring their success. What we have learned from this study, then, is that we need to extend our efforts beyond attempting to develop and deliver a good programme to also consider the following:

\section{Raise awareness of the role of language in university study}

As teachers and researchers we are aware of the importance of having good language proficiency and the consequences of not having it. We should try to communicate this to our students and perhaps use role models (both positive and negative) to encourage them to make time to improve their language skills. Students will need to make the everimportant first step and unless we are able to motivate them to take that step, we will not be able to help them.

\section{Give students credit for their work}

Many students feel overwhelmed, especially in the first year. The language, the new culture, and the experience of being away from home all 
combine to put an enormous amount of pressure on them. Asking students to spend extra time in a self-access centre or to take a programme without any immediate recognition of their time investment may be asking too much. We are now experimenting with various departments who have agreed to give their students a percentage of their course marks for completing language self-study. In the Self-Access Centre we keep track of the number of times they come and the amount of time they study. This information is passed on to the departments and the students get credit for their work. The time investment on the part of the departments (as in the reduced amount of time available for teaching the content) pays off in that students are able to work more efficiently and dropout rates are lower. This way more progress can be made in the long run.

\section{Highlight the importance of learning skills}

Many students may have been unfamiliar with the goals of the support programme. As suggested above, a focus on skills for learning a language, rather than on the content of the language may have seemed inefficient and maybe even strange to some. If we believe in the importance of developing our students as independent learners, then we need to start by convincing them of the merits of this. Perhaps by sharing the rationale behind our approach and by giving clear examples of how this approach can benefit them, we will be able to motivate them better. Perhaps there may even be a role for teachers in students' home countries, such as Japan. The figures reported in this article show many students' language proficiency causes them to be ill prepared for their studies, and in need of ongoing language development. The ability to identify language needs and to seek out opportunities for improvement is crucial. However, this is not an ability that many students are born with and that generally requires a considerable amount of training. Once students embark on their studies, little time is left to develop these skills. The fact that for Japanese students both performance on the assessment and their participation in the support programme was low was not investigated further as it was not one of the research questions of the study. However, in the context of this article it is worth mentioning that anecdotal feedback from the Centre staff shows Japanese students to be particularly unprepared for independent study and to be in need of a great deal of support. Here, there is a clear role for teachers involved in predeparture language training.

Although the participation and completion figures of this programme were disappointing, the reflection this prompted has helped us to iden- 
tify some important mismatches between what the programme intended to do and how the students perceived the programme. This has encouraged us to reconsider how we promote our services and more generally our role in supporting second language students in our institution. It is hoped that the results from this study will also help raise awareness among teachers preparing students for overseas study as to the level of difficulty many of students face once they arrive. This study has shown a clear need for students to not only expect to have to further improve their English, but also to have the independent learning skills to do so.

Hayo Reinders (www.hayo.nl) is Visiting Professor at Meiji University, Tokyo. He is also Director of the English Language Self-Access Centre at the University of Auckland. Hayo is coeditor of PacCall Journal and coordinates the Learner Autonomy Project Inventory for the AILA Scientific Commission for Learner Autonomy.

\section{Notes}

1. The author would like to acknowledge the help of Keiko Sakui and Motoko Akakura in administering the questionnaires and collating the results.

\section{References}

Ballard, B., \& Clanchy, J. (1997). Teaching international students: A brief guide for lecturers and supervisors. Deakin: IDP Australia.

Benson, P., \& Voller, P., (Eds.). (1997). Autonomy and independence in language learning. London: Longman.

Cotterall, S., \& Reinders, H. (2001). Fortress or bridge? Learners' perceptions and practice in self-access language learning. Tesolanz, 8, 23-38.

Elder, C. (2004). Report of the diagnostic English language needs analysis. Auckland: University of Auckland.

Fu, G. (1999). Guidelines for productive language counselling: Tools for implementing autonomy. In S. Cotterall \& D. Crabbe. (Eds.), Learner autonomy in language learning: Defining the field and effecting change (pp. 107-111). Frankfurt am Main: Peter Lang.

Hiemstra, R., \& Brockett, R. (Eds.). (1994). Overcoming resistance to self-direction in adult learning. London: Jossey-Bass. 
Mak, B., \& Turnbull, M. (1999). The personalised English programme: Piloting structured language learning support in a university self-access centre. In B. Morrisson (Ed.), Experiments and evaluation in self-access language learning (pp. 43-59). Hong Kong: Hong Kong Association for Self-Access Learning and Development.

Mozzon-McPherson, M., \& Vismans, R. (Eds.). (2001). Beyond language teaching towards language advising. London: Cilt.

Pemberton, R., Ho, S., Lam, J., \& Toogood, S. (1999). Developing a self-directed English language-learning programme for postgraduate students. In B. Morrisson (Ed.), Experiments and evaluation in self-access language learning (pp. 1-24). Hong Kong: Hong Kong Association for Self-Access Learning and Development.

Reinders, H. (in press a). Supporting self-directed learning through an electronic learning environment. In T. Lamb \& H. Reinders (Eds.), Supporting selfdirected language learning. Frankfurt am Main: Peter Lang.

Reinders, H. (in press b). University counselling: Is it useful? In Fostering partnership in language teaching and learning. Hong Kong: University of Hong Kong.

Reinders, H., \& Cotterall, S. (2001). Language learners learning independently: How autonomous are they? TTWiA, 65, 85-97.

Tsang, E. (1999). Resistance to self-access learning. In B. Morrisson (Ed.), Experiments and evaluation in self-access language learning (pp. 25-42). Hong Kong: Hong Kong Polytechnic University.

Voller, P., Martyn, E., \& Pickard, V. (1999). One-to-one counselling for autonomous learning in a self-access centre: Final report on an action learning project. In S. Cotterall \& D. Crabbe (Eds.), Learner autonomy in language learning: Defining the field and effecting change (pp. 111-128). Frankfurt am Main: Peter Lang. 
Appendix A

\section{Nonparticipants' questionnaire}

The questionnaire below was administered on a website where participants answered the questions on screen. It included additional questions about participants' age, study, and other background questions, as well as a page with instructions.

1) Having good English ability is important to be a successful student.

\begin{tabular}{llllll}
6 & 5 & 4 & 3 & 2 & 1 \\
\hline
\end{tabular}

2) I need to improve my English.

\begin{tabular}{llllll}
6 & 5 & 4 & 3 & 2 & 1 \\
\hline
\end{tabular}

3) Which language skill do you need to improve the most?

Listening

Reading

Writing

Speaking

4) Have you heard of ELSAC?

Yes

No

5) Our records show that you were invited to join an English study programme at ELSAC, but that you did not join the programme. Can you tell us why?

a) I want to study English with a teacher.

\begin{tabular}{llllll}
6 & 5 & 4 & 3 & 2 & 1 \\
\hline
\end{tabular}


b) I am too busy to go to the ELSAC.

\begin{tabular}{llllll}
6 & 5 & 4 & 3 & 2 & 1 \\
\hline
\end{tabular}

c) I think my English will gradually improve without going to the ELSAC.

\begin{tabular}{llllll}
6 & 5 & 4 & 3 & 2 & 1 \\
\hline
\end{tabular}

d) I have other ways to improve English.

\begin{tabular}{llllll}
6 & 5 & 4 & 3 & 2 & 1 \\
\hline
\end{tabular}

e) I am planning to go to the ELSAC but haven't yet made the first step.

\begin{tabular}{llllll}
6 & 5 & 4 & 3 & 2 & 1 \\
\hline
\end{tabular}

6) What type of help would you want from ELSAC?

a) help with deciding what [I] need to work on to improve [my] English

\begin{tabular}{llllll}
6 & 5 & 4 & 3 & 2 & 1 \\
\hline
\end{tabular}

b) many language learning materials such as books and CDROMs

\begin{tabular}{llllll}
6 & 5 & 4 & 3 & 2 & 1 \\
\hline
\end{tabular}

c) advice on the best way to learn a language

\begin{tabular}{llllll}
6 & 5 & 4 & 3 & 2 & 1 \\
\hline
\end{tabular}


d) someone to proofread my writing

\begin{tabular}{llllll}
6 & 5 & 4 & 3 & 2 & 1 \\
\hline
\end{tabular}

e) workshops and language learning activities with a teacher

\begin{tabular}{llllll}
6 & 5 & 4 & 3 & 2 & 1 \\
\hline
\end{tabular}

f) a quiet place to study

\begin{tabular}{llllll}
6 & 5 & 4 & 3 & 2 & 1 \\
\hline
\end{tabular}

g) advice on what materials to use

\begin{tabular}{llllll}
6 & 5 & 4 & 3 & 2 & 1 \\
\hline
\end{tabular}

h) a chance to meet other students to study English together

\begin{tabular}{llllll}
6 & 5 & 4 & 3 & 2 & 1 \\
\hline
\end{tabular}

7) Do you have any ideas for ELSAC to best help the students? 


\section{Appendix B}

\section{Participants' questionnaire}

The original questionnaire included additional background questions and instructions.

\begin{tabular}{|c|c|c|c|c|c|c|}
\hline \multicolumn{2}{|r|}{ Question } & 5 & 4 & 3 & 2 & 1 \\
\hline 1 & $\begin{array}{l}\text { How useful did you find the advisory ses- } \\
\text { sions? }\end{array}$ & & & & & \\
\hline 2 & $\begin{array}{l}\text { Do you think the advisory sessions helped } \\
\text { you learn how to study English by yourself } \\
\text { in the future? }\end{array}$ & & & & & \\
\hline 3 & $\begin{array}{l}\text { Do you think the advisory sessions helped } \\
\text { you focus on what you want to improve in } \\
\text { your English? }\end{array}$ & & & & & \\
\hline 4 & $\begin{array}{l}\text { Have the advisory sessions helped you to } \\
\text { set manageable goals for yourself? }\end{array}$ & & & & & \\
\hline 5 & $\begin{array}{l}\text { Have the advisory sessions helped you to } \\
\text { assess your progress and achievement? }\end{array}$ & & & & & \\
\hline 7 & $\begin{array}{l}\text { Have the advisory sessions helped you to } \\
\text { develop new learning strategies? }\end{array}$ & & & & & \\
\hline 9 & $\begin{array}{l}\text { Do you feel that the advisory sessions } \\
\text { made you work on your English more? }\end{array}$ & & & & & \\
\hline 10 & $\begin{array}{l}\text { Did you feel supported by your language } \\
\text { adviser? }\end{array}$ & & & & & \\
\hline 11 & $\begin{array}{l}\text { How useful did you find the weekly study } \\
\text { plan? }\end{array}$ & & & & & \\
\hline 12 & $\begin{array}{l}\text { How often did you look at your weekly } \\
\text { study plan in between meetings with the } \\
\text { your language advisor? }\end{array}$ & & & & & \\
\hline
\end{tabular}

13) What aspects of the advisory sessions have you found the most useful?

14) What learning strategies did you develop as a result of attending the advisory sessions?

15) Do you have any suggestions that could help us improve the advisory sessions? 